\title{
Pulmonary involvement in disseminated varicella infection in an adult
}

\author{
Navneet Arora (10 , ${ }^{1}$ Prasanna Bhat, ${ }^{1}$ Priyansh Gupta, ${ }^{2}$ Harpreet Singh ${ }^{1}$
}

${ }^{1}$ Internal Medicine, Post Graduate Institute of Medical Education and Research, Chandigarh, India ${ }^{2}$ Dermatology, Post Graduate Institute of Medical Education and Research, Chandigarh, India

\section{Correspondence to}

Dr Harpreet Singh;

hs.30.singh@gmail.com

Accepted 7 December 2021

\section{DESCRIPTION}

A 35-year-old man with coeliac disease treated with prednisolone presented to the emergency department with a 7 day history of fever and pruritic rash over the face, trunk and limbs. For the past 4 days, he developed a non-productive cough and breathlessness at rest. $\mathrm{He}$ had a pulse rate of 118 beats per minute, respiratory rate of 32 breaths per minute and oxygen saturation of $92 \%$ by a non-rebreathing mask. He had multiple papulovesicular and pustular lesions of varying ages. Some crusted vesicles were distributed over the head, neck, trunk (figure 1A) and limbs, and the Tzanck smear of the same showed large multinucleated giant cells signifying varicella infection (figure 1B). Chest auscultation revealed bilateral basal crepitation. A plain radiograph of the chest revealed multiple nodules coalescing to form nodular consolidation and infiltrates in both lungs (figure 2). He was diagnosed with disseminated varicella infection with varicella pneumonia presenting as acute respiratory distress syndrome. He was treated with intravenous acyclovir, oxygen supplementation and was subsequently put on mechanical ventilation. Despite the treatment, his condition continued to worsen, and he succumbed to his illness within 24 hours of presentation. Pulmonary involvement is seen in 5\%-15\% of the adult varicella patients, ${ }^{1}$ which is associated with high mortality rates, up to $50 \%$, especially among immunocompromised individuals. Any immunosuppression that affects the cell-mediated immunity increases the risk of varicella infection, including HIV infection, prolonged treatment with steroids, cancer or diabetes mellitus. ${ }^{2}$ Radiographic findings are non-specific and include ill-defined or well-defined nodules with surrounding ground-glass opacity distributed diffusely in lung fields. ${ }^{34}$ Diagnosis is mainly based on the typical skin lesions, Tzanck smear findings and pulmonary involvement. Treatment includes early initiation of intravenous acyclovir for 14 days, oxygen supplementation and supportive care.

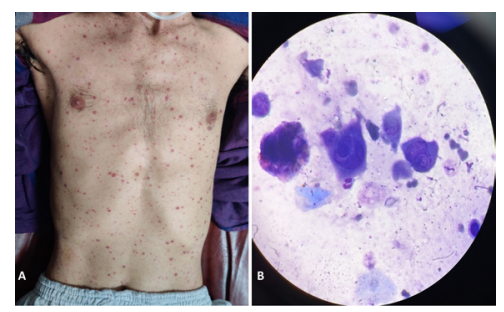

Figure 1 (A) Multiple papulovesicular and pustular lesions of varying age with some crusted vesicles distributed over the head, neck, trunk and limbs. (B) Tzanck smear showing large multinucleated giant cells suggestive of varicella-zoster (Tzanck, 100x).

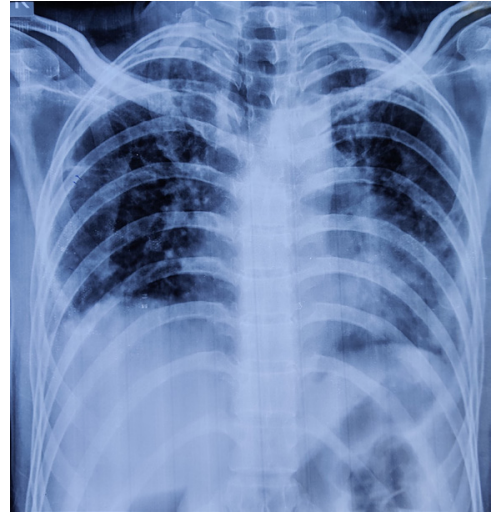

Figure 2 Plain radiograph of the chest showing multiple nodules coalescing to form nodular consolidation and infiltrates in both lungs.

\section{Learning points}

- Pulmonary involvement is infrequent and ranges from $5 \%$ to $15 \%$ of adult varicella patients.

- Mortality is as high as $50 \%$ in disseminated varicella infection even after aggressive treatment.

- Diagnosis is mainly based on the typical skin lesions, Tzanck smear findings and pulmonary involvement.

Contributors NA written the original draft and patient management; PB patient management; PG Tzanck smear and legends and HS manuscript supervision and expert guidance.

Funding The authors have not declared a specific grant for this research from any funding agency in the public, commercial or not-for-profit sectors.

\section{Competing interests None declared.}

Patient consent for publication Consent obtained directly from patient(s).

Provenance and peer review Not commissioned; externally peer reviewed.

Case reports provide a valuable learning resource for the scientific community and can indicate areas of interest for future research. They should not be used in isolation to guide treatment choices or public health policy.

\section{ORCID iD}

Navneet Arora http://orcid.org/0000-0002-4507-2468

\section{REFERENCES}

1 Tunbridge AJ, Breuer J, Jeffery KJM, et al. Chickenpox in adultsclinical management. J Infect 2008;57:95-102.

2 Thomas SL, Hall AJ. What does epidemiology tell us about risk factors for herpes zoster? Lancet Infect Dis 2004;4:26-33. 


\section{Images in...}

3 Abba AA, Al-Khuwaitir TS, Al-Moghairi AM, et al. Presentation and outcome of varicella pneumonia in adults. Saudi Med J 2005;26:338-40.

4 Pannu AK, Manikandan G. Disseminated varicella infection. N Eng/ J Med 2019;381:e21.

Copyright 2021 BMJ Publishing Group. All rights reserved. For permission to reuse any of this content visit

https://www.bmj.com/company/products-services/rights-and-licensing/permissions/

BMJ Case Report Fellows may re-use this article for personal use and teaching without any further permission.

Become a Fellow of BMJ Case Reports today and you can:

- Submit as many cases as you like

- Enjoy fast sympathetic peer review and rapid publication of accepted articles

- Access all the published articles

Re-use any of the published material for personal use and teaching without further permission

Customer Service

If you have any further queries about your subscription, please contact our customer services team on +44 (0) 2071111105 or via email at support@bmj.com.

Visit casereports.bmj.com for more articles like this and to become a Fellow 